\title{
Top Companies Ranking Based on Financial Ratio with AHP-TOPSIS Combined Approach and Indices of Tehran Stock Exchange
}

\section{A Comparative Study}

\author{
Seyed-Hasan Hosseini ${ }^{1}$, Mohammad Esmaeil Ezazi ${ }^{1}$, Mohamad Rasoul Heshmati ${ }^{2}$ \& Seyed-Mohamad Reza \\ Hosseini Moghadam ${ }^{2}$ \\ ${ }^{1}$ Faculty of Management and economics, School of Business management, University of Sistan and Baluchestan, \\ Zahedan, Iran \\ 2 Departments of Management, Faculty of Economic and Administrative Sciences, Ferdowsi University of \\ Mashhad, Mashhad, Iran
}

Correspondence: Seyed-Hasan Hosseini, Faculty of accounting and management, School of financial management, University of Sistan and Baluchestan, Zahedan, P.O. Box: 98155-987, Iran. Tel: 98-91-4841-1580. E-mail: hasan_hosseini96@yahoo.com

Received: December 3, $2012 \quad$ Accepted: January 14, $2013 \quad$ Online Published: February 22, 2013

doi:10.5539/ijef.v5n3p126 URL: http://dx.doi.org/10.5539/ijef.v5n3p126

\begin{abstract}
This paper aims to explore the relationship between ranking of the top-50 listed companies on Tehran Stock Exchange (TSE) for the years 2009- 2011 in terms of their liquidity, operation, leverage and profitability ratios using combined AHP-TOPSIS approach and the ranking made by the stock exchange. Ranking of the companies on the stock exchange is done based on their state in terms of the above ratios and it serves as a criterion for decision making on investment. Using a questionnaire, views of experts, scholars and the capital market authorities on the effect of financial ratios were gathered and then using AHP- TOPSIS technique the companies were ranked based on these ratios. The obtained results from the Spearman Test show a weak correlation between the rankings based on AHP-TOPSIS approach and the ranking of the stock exchange. Finally, our results indicate that financial ratios of the top stock exchange selected companies are crucial factors in investment and ranking. This paper contributes to a signaled need for investigation on how and why financial statements of top listed companies cannot be regarded as a critical factor in ranking and decision making on investment.
\end{abstract}

Keywords: AHP-TOPSIS, financial ratios, ranking, Tehran Stock Exchange (TSE)

\section{Introducation}

\subsection{Introduce the Problem}

Companies ranking is a practical tool for distinguishing companies in distress from the healthy ones. Ranking also guarantees survival of companies ( $\mathrm{Li} \&$ Sun, 2008). It is necessary to make a great number of business decisions, e.g. in case of investment decisions, loan granting, and generally in case of establishment of any business relationship. In recent years, many developed countries by foundation of capital market (i.e. foundation of stock exchanges and over the counter markets (OTC) have secured their economic development (Babic\&Plazibat, 1998). Development of stock exchange and OTC has resulted in generation and expansion of financial services which at different levels provide investors with consultation services and rank companies and stock exchanges (O'Hara \& Vetere,1993).Investors, managers, creditors and in general, stakeholders each using some criteria measuring business unit and its performance. In this regard, analysis of financial statements can be a right solution for evaluation and ranking of companies. Ranking can reveal weaknesses and strengths of the companies as well as opportunities and threats for them. In fact, it is a full-length mirror reflecting their state of affairs. This tool has very crucial role in decisions regarding companies' trading, investments and financing (Conner, 1973).

Sometimes, decision maker uses knowledge and experience based models simultaneously and often by accurate evaluations and application of various methods (Babic\&Plazibat, 1998). Different criteria may be applied to 
company ranking using particular indicators and different ranking methods. In the Iranian capital market, due to absence of financial services institutes, the current reliable ranking is the ranking made by the stock exchange. One of the published reports concerns the report on the top listed companies on the stock exchange which is prepared based on share liquidity, amount of company's investment in the market and company's situation in terms of financial excellence using harmonic mean method. Ranking is a complex and multi-criteria concept which, given its calculation simplicity and optimality, serves as a suitable tool to examine and analyze the enterprise excellence and its situation.

\subsection{Explore Importance of the Problem}

In this research, for prioritization and ranking of the top-50 listed companies based on their financial ratios and then comparing it with the ranking of the stock exchange, Analytic Hierarchy Process (AHP) technique in the hand of each key indicator (liquidity, leverage, operation and profitability ratios) was employed, while a relative weight was assigned to each sub-indicator. Next, using Technique for Order Preferences by Similarity Ideal Solution (TOPSIS) the under study firms were ranked based on each one of these indicators. Finally, the obtained ranking was compared with the ranking provided by the stock exchange and based on the stock exchange's indices and then their correlation was examined. In fact, we will use the TOPSIS method for final ranking and analytic hierarchy process to determine the importance of the criteria in the top-50 listed companies in terms of liquidity, operational, leverage and profitability ratio.

\subsection{An Overview of Ranking Based on Different Criteria}

Studies on indices of successful companies indicate a significant relationship between firms ranking based on performance measurement criteria and financial criteria (Johnson \&Soenen, 2003).Another study in S\&P index revealed that such factors as share price, sales, and profit margin suggested higher rating of favorable factors for high ranking firms (Polonchek\&Krehbiel, 1994). Following the prior research, Omran and Ragab (2004) examined presence of a linear relationship between share return and financial ratios and then investigated presence of a linear relationship between share return and financial ratios (Omran\&Ragab, 2004) .They found that the ratio return on equity (ROE) was significant for all models. Hassanzadeh et al (2010) in their study found that there is a significant association between firms' financial ratios and bank managers' decision on granting them credit(Hassanzadeh\& et all,2010).Lev and Thiagrajan (1993) following Penman's studies and using financial ratios concluded that fundamental signals are associated to share return(Lev \& Thiagrajan,1993).In addition, recent findings suggest that although financial information plays a crucial role in prediction of return on investment (ROI), yet the effect of each financial factor depends on market condition and under this condition this effect is not stable(Knif\& Miranda,2000).Besides, other studies indicate that financial statements and financial ratios are used for distinction of successful companies from unsuccessful ones (Piotroski,2000;Mohanram,2005;Michou,2007). Their results indicate that companies with a higher book-tomarket value have a higher return on average.

\section{Method}

This research is of descriptive-correlation type in which top-fifty listed companies for the period 2009-2011 were examined by census. The research statistical data was gathered by referring to the Securities and Exchange Organization (SEO) and using Rahavard-e-Novin software. The top-50 listed companies on TSE are presented in the table in each one of the under study years according to their industry.

Table 1. Top-50 listed companies on tse in each one of the under study years per industry

\begin{tabular}{lccc}
\hline Industry type & $\mathbf{2 0 0 9}$ & $\mathbf{2 0 1 0}$ & $\mathbf{2 0 1 1}$ \\
\hline Financial brokers, investment \& holding & 19 & 22 & 19 \\
Cement, lime, chalk \& metal ore extraction & 6 & 4 & 6 \\
Automobile manufacturing \& base metals & 10 & 11 & 9 \\
Food and chemical products & 6 & 4 & 4 \\
Pharmaceutical materials\& products & 3 & 5 & 3 \\
Miscellaneous industries & 6 & 4 & 9 \\
\hline Total (Number) & 50 & 50 & 50 \\
\hline
\end{tabular}

In present research, for the purpose of ranking based on financial ratios, a questionnaire was composed by means of which weight of financial ratio in the ranking is obtained. Once the questionnaire's validity has been confirmed, its reliability using inconsistency rate was found to be 0.06 which was smaller than 0.1 and hence 
approved. Next, the questionnaire was handed out to 20 experts and respective officials of the capital market as well as professors of finance and accounting from various universities and they were asked to give their opinion on the question as to what extent each one of the financial ratios should be considered as a critical indicator in firms ranking. Given the type, purpose, hypotheses and questionnaire of the research, a 1-to-9-hour scale was employed to form the matrix of paired comparisons in order to evaluate weight of the indicators and to rank companies using AHP and TOPSIS techniques. In the next step, using AHP technique and Expert Choice software, the indicators were assigned weight and then profiting from TOPSIS technique under TOPSIS (2005) software the firms were ranked. Finally, utilizing SPSS software, Spearman Correlation Coefficient $\left(r_{s}\right)$ and relation (1) were used to examine and analyze the correlation between the rankings and its significance.

$$
r_{s}=1-\frac{6\left(\sum \mathrm{d}_{\mathrm{i}}^{2}\right)}{n\left(n^{2}-1\right)}
$$

In this relation, $\mathrm{n}$ is the number of data, $\sum\left(\mathbf{d}_{\mathrm{i}}^{2}\right)$ is the sum of square difference between rankings of two variables $\mathrm{x}$ and $\mathrm{y}$. Variable $\mathrm{x}$ represents firms ranking based on the stock exchange indices and variable y represents firms ranking based on financial ratios in the combined AHP-TOPSIS approach. To study the correlation significance, relation 2 is utilized:

Where the statistical hypotheses are:

$$
t=1-\frac{r-\rho}{\sqrt{\frac{1-r^{2}}{n-2}}}
$$

$\mathbf{H}_{\mathbf{0}}: \boldsymbol{\rho}=\mathbf{0}$, there is no significant relationship.

$\mathbf{H}_{1}: \boldsymbol{\rho} \neq \mathbf{0}$, there is significant relationship

In addition, given the obtained correlation coefficient value, and intensity and direction of the relationship, method of weight assignment to ratios and firms ranking is determined. The indicators have been selected conform to opinion of a group of experts and managers. Another expert group might have selected a somewhat different set of indicators, yet this would not affect the main idea in this research. As was stated, this research aims to form a methodological framework and to propose a model which can substitute the composed indicator for companies ranking. To assign weight and generalize experts' view on the four understudy financial criteria (financial ratios), AHP technique was employed. In this technique, after construction of the model and development of the decision tree (hierarchy structure), the matrix of paired comparisons for indicators which represents significance and priority of the index $\mathrm{i}$ relative to index $\mathrm{j}$ was formed and subsequently de-scaled. Next, matrix inconsistency rate was calculated and finally, for prioritization and ranking of the top-50 companies, relative weight of the indicators was obtained, as is presented in Table 2 and Figure 1.

Table 2. Matrix of paired comparisons of research's chief criteria in expert choice

\begin{tabular}{lcccc}
\hline Chief criteria & Liquidity ratio & operational ratio & Leverage ratio & Profitability ratio \\
\hline Liquidity ratio & 1 & 0.33 & 0.5 & 0.2 \\
operational ratio & & 1 & 3.5 & 0.5 \\
Leverage ratio & & & 1 & 0.5 \\
Profitability ratio & & & & 1 \\
\hline
\end{tabular}

Notes: Liquidity: 0.0.86, operation: 0.322, Leverage: 0.153, Profitability: 0.438 .

As is seen, profitability ratio with a relative weight of 0.438 has the highest significance and the index liquidity ratio with a relative weight of 0.086 has the least significance. A paired comparisons inconsistency rate of 0.06 was obtained which is smaller than 0.10 . Hence, we infer that these comparisons have a reasonable consistency. Sub-criteria's relative weight compared to chief criteria (four financial ratios) and their prioritization in Expert Choice software are presented in figures 2 and 5 according to which relative weight of the four chief criteria was obtained. 


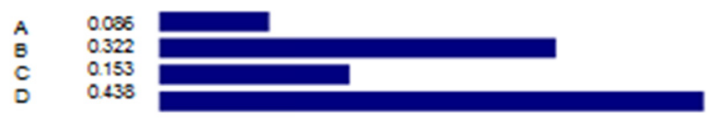

Inconsistency $=0.06$

Figure1. Prioritization of four chief criteria (financial ratio) according to Expert Choice software

(A: Liquidity; B: Operation; C: Leverage; D: Profitability)

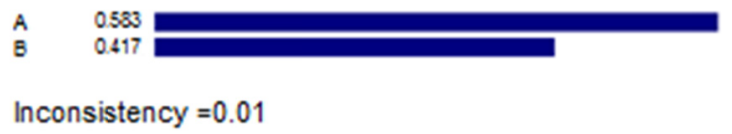

Figure2. Prioritization of liquidity ratio using Expert Choice software

(A: Current; B: Instant)

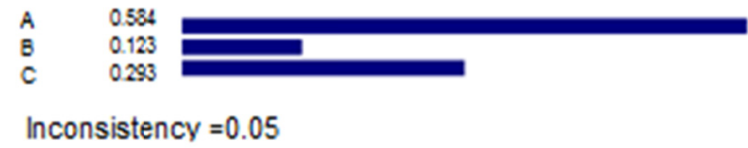

Figure 3. Prioritization of operation ratio using Expert Choice software

(A: Period of receiving claims; B: Inventory flow; C: Assets flow)

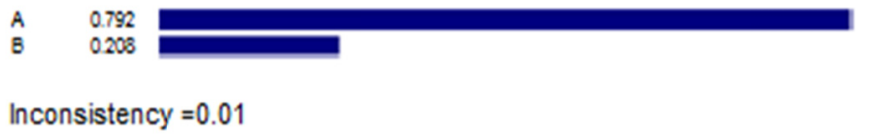

Figure 4. Prioritization of Leverage ratio using Expert Choice software

(A: Debt to equity ratio; B: Debt ratio)

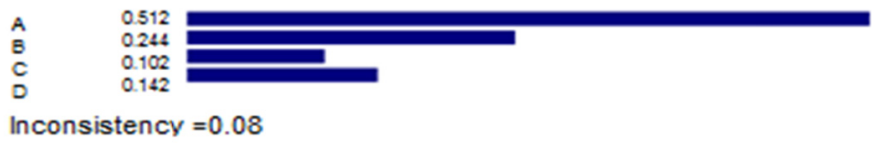

Figure 5. Prioritization of profitability ratio using Expert Choice software

(A: Profit margin; B: ROE; C: ROA; D: ROI)

Following this process, to apply TOPSIS technique to ranking of the top-50 companies based on each one of the financial ratios and choice of the best option from among the available options, first, decision making matrix is formed and using entropy weight assignment method the indicators are assigned a weight. To de-scale the indicators' measurement units and to allow algebraic operation on them, each element of decision matrix using relation 3 is standardized and finally the de-scaled matrix is built.

$$
n_{i j}=\frac{\mathrm{x}_{\mathrm{ij}}}{\sqrt{\sum_{\mathrm{i}=1}^{\mathrm{m}} \mathrm{x}^{2} \mathrm{ij}}}
$$

Next, the weighted de-scaled matrix and positive $\left(\mathrm{A}^{+}\right)$and negative $\left(\mathrm{A}^{-}\right)$focuses were calculated. To find the 
answer of positive and negative focuses for the indices, relations 4 and 5 are used.

$$
\begin{aligned}
& A^{+}=\left\{\vartheta_{1}^{+}, \vartheta_{2}^{+}, \ldots . ., \vartheta_{1}^{+}\right\}=\left\{\left(\max _{i} \vartheta_{i j} \mid j \epsilon j^{+}\right),\left(\min _{i} \vartheta_{i j} \mid j \epsilon j^{-}\right) \mid i=1,2, \ldots \ldots, m\right\} \\
& A^{-}=\left\{\vartheta_{1}^{-}, \vartheta_{2}^{-}, \ldots . ., \vartheta_{1}^{-}\right\}=\left\{\left(\min _{i} \vartheta_{i j} \mid j \epsilon j^{+}\right),\left(\max _{i} \vartheta_{i j} \mid j \epsilon j^{-}\right) \mid i=1,2, \ldots \ldots, m\right\}
\end{aligned}
$$

In these relations, $\mathrm{J}^{+}$and $\mathrm{J}^{-}$represent the indicator sets of positive and negative indicators in decision making, respectively. Answer of the focuses for each indicator in each year is presented in Table 3.

Table 3. Positive and negative focuses for each index in each year

\begin{tabular}{llcccc}
\hline Year & $\mathrm{A}^{+}$and $\mathrm{A}^{-}$ & Profitability & Leverage & Operation & Liquidity \\
\hline \multirow{2}{*}{2009} & $A^{+}=\left\{\vartheta_{1}^{+}, \vartheta_{2}^{+}, \ldots \ldots, \vartheta_{1}^{+}\right\}$ & 0.0622 & 0.0003 & 0.0092 & 0.0068 \\
& $A^{-}=\left\{\vartheta_{1}^{-}, \vartheta_{2}^{-}, \ldots ., \vartheta_{1}^{-}\right\}$ & -0.0090 & 0.0084 & -0.0013 & 0.0004 \\
& $A^{+}=\left\{\vartheta_{1}^{+}, \vartheta_{2}^{+}, \ldots \ldots, \vartheta_{1}^{+}\right\}$ & 0.0209 & 0.0000 & 0.0580 & 0.0172 \\
& $A^{-}=\left\{\vartheta_{1}^{-}, \vartheta_{2}^{-}, \ldots \ldots, \vartheta_{1}^{-}\right\}$ & -0.0160 & 0.0071 & 0.0000 & 0.0004 \\
& $A^{+}=\left\{\vartheta_{1}^{+}, \vartheta_{2}^{+}, \ldots \ldots, \vartheta_{1}^{+}\right\}$ & 0.0398 & 0.0000 & 0.0292 & 0.0122 \\
& $A^{-}=\left\{\vartheta_{1}^{-}, \vartheta_{2}^{-}, \ldots \ldots, \vartheta_{1}^{-}\right\}$ & 0.0005 & 0.0067 & 0.0000 & 0.0000 \\
\hline
\end{tabular}

In the next stage, using relations 6 and 7 which respectively represent indicators difference from positive focus and negative focus for option i, Euclidean difference of each option was calculated:

$$
\begin{gathered}
D_{i}^{+}=\sqrt{\sum_{j=1}^{n}\left(\vartheta_{i j}-\vartheta_{j}^{+}\right)^{2}} \rightarrow i=1,2, \ldots \ldots, m \\
D_{i}^{-}=\sqrt{\sum_{j=1}^{n}\left(\vartheta_{i j}-\vartheta_{j}^{-}\right)^{2}} \rightarrow i=1,2, \ldots ., m
\end{gathered}
$$

Having found all the positive and negative spaces, each decision option was determined by linking it to a number (8). It is noteworthy that the result should always be between 0 and 1 .

$$
C L_{i}=\frac{D_{i}^{-}}{D_{i}^{-}+D_{i}^{+}} \rightarrow i=1,2, \ldots, m, \quad 0 \leq C L_{i} \leq 1
$$

Finally, the firms were ranked per year and indicators (financial ratios), so as the greater the relative distance $\left(\mathrm{CL}_{\mathrm{i}}\right)$ of decision making options is and the closer they are to (1), the higher their priority and rank will be.

\section{Results}

The hypothesis of this study suggests that most companies with appropriate financial ratios in terms of liquidity, operation, leverage and profitability ratios have a higher rank. So such companies enjoy a higher priority. Now to prove this claim, we need to find a significant relationship between two types of rankings based on proportion of each ratio. Given the large number of the group financial brokerage firms, investment, and holding among the top listed companies, the correlation between the two rankings has been analyzed with and without inclusion of this group of companies. Table 4 presents the results obtained from test of the hypotheses and correlation coefficient between these two types of ranking. In this research, given the proposed hypotheses, five correlations between the rankings were specified and calculated and analyzed based on all or each one of the financial ratios (Table 4). In analysis of the main hypothesis, there an inverse relationship was found between two types of ranking with and without presence of financial brokerage, investment and holding companies in 2009 but this relationship in 2010-2011 has turned into a direct relationship, indicating a doubled interest in ranking and investors' investment relative to the past. Given the stronger and greater correlation, if financial brokerage, investment and holding companies are excluded from the group of the superior firms, it can be said that relationship between ranking of other companies by the stock exchange and their ranking based on financial ratio using AHP-TOPSIS approach becomes more aligned. With regard to the sub-hypothesis liquidity, correlation coefficient with and without presence of financial brokerage, investment and holding companies was positive in 
all three years, indicating a direct relationship. Hence, it can be stated that in each year relative to previous year, attention to liquidity ratio has increased in the ranking and investment. In addition, there is no difference between financial brokerage, investment and holding companies and other companies regarding convergence of the ranking by the stock exchange and that based on the financial ratios using AHP-TOPSIS technique.

In the second sub-hypothesis, correlation coefficient was negative in all the three years of 2009-2011 and its intensity has increased year by year. This indicates a greater inverse attitude to the operation ratio in the ranking by the stock exchange during the time period in question and investors have had greater negative attitude to this ratio as well as to share trading. However, as is seen, with exclusion of financial brokerage, investment and holding companies, the inverse correlation in 2009 has turned into a direct correlation in 2010 and again into inverse correlation in 2011. This suggests a greater interest in operation ratio in the ranking of other companies during 2010 and the relationship between ranking of these companies by the stock exchange and their ranking based on operation ratios using AHP-TOPSIS approach has had more convergence in this year. But this attitude and convergence has been weakened in 2011. The obtained results regarding the third sub-hypothesis, confirms that the negative and very weak correlation in 2009 has turned into a positive correlation in 2010-2011 and intensity of this relationship has enhanced. This change in the relationship direction indicates the positive and greater interest in leverage ratio in ranking or investors' positive attention to leverage ratio in their share trading and investment. This finding is more remarkable in case of exclusion of financial brokerage, investment and holding companies in 2011. Finally, the obtained results in Table 4 indicate that intensity and direction of relationship of the ratio profitability from negative in 2009 at increasing rate has turned into positive relationship in the next years, in the sense that during the under study years, in each year relative to previous year, greater and more positive attitude towards profitability ratio has been observed in the ranking and in fact, investors have shown increasingly greater and more positive attitude to share reading and their investment in each year compared to previous year and this trend has been intensified by exclusion of financial brokerage, investment and holding companies.

\section{Discussion}

Firms ranking, while promoting competition and market efficiency, is a useful guide for investors and market operators. The results obtained from study of correlation between the ranks made by the financial ratios using AHP-TOPSIS combined approach and those by indicators of the stock exchange regarding top-50 listed companies in the years 2009- 2011 indicate that in 2009, there is an inverse relationship (with and without presence of financial brokerage, investment and holding companies) between these two types of ranking, in the sense that contrary to our expectation, the higher ranked companies on the stock exchange, were not ranked as much higher based on the financial ratios of 2009. This relationship in the years 2009 and 2010 with an increasing correlation coefficient has turned into a direct correlation. It means that a doubled attention has been paid to financial ratios in ranking and investment decisions. In addition, the companies other than financial brokerage; investment and holding have shown more convergence in these two types of ranking. In general, it can be said that there is no significant association between ranking of the top-50 TSE listed companies based on financial ratios in AHP-TOPSIS combined approach and their ranking based on the indicators of the stock exchange and the presented items in firms' financial statements are not regarded an adequate approximation for their estimation of their excellence. 
Table 4. Correlations between the rankings of TSE and AHP-TOPSIS approach based on financial ratios

\begin{tabular}{|c|c|c|c|c|c|c|c|}
\hline \multirow[b]{2}{*}{ Hypothesis } & & \multicolumn{2}{|c|}{2009} & \multicolumn{2}{|c|}{2010} & \multicolumn{2}{|c|}{2011} \\
\hline & & $\begin{array}{c}\text { Correlation } \\
\text { coefficient }\end{array}$ & $\begin{array}{c}\text { Relationship } \\
\text { intensity \& } \\
\text { direction } \\
\end{array}$ & $\begin{array}{c}\text { Correlation } \\
\text { coefficient }\end{array}$ & $\begin{array}{c}\text { Relationship } \\
\text { intensity \& } \\
\text { direction } \\
\end{array}$ & $\begin{array}{c}\text { Correlation } \\
\text { coefficient }\end{array}$ & $\begin{array}{c}\text { Relationship } \\
\text { intensity \& } \\
\text { direction } \\
\end{array}$ \\
\hline \multirow{2}{*}{$\begin{array}{c}\text { financial } \\
\text { ratio }\end{array}$} & A & -0.306 & $\begin{array}{c}\text { Negative \& } \\
\text { relatively weak }\end{array}$ & 0.116 & $\begin{array}{l}\text { Positive \& } \\
\text { very weak }\end{array}$ & 0.224 & $\begin{array}{l}\text { Positive \& } \\
\text { weak }\end{array}$ \\
\hline & B & -0.171 & $\begin{array}{c}\text { Negative \& } \\
\text { weak }\end{array}$ & 0.145 & $\begin{array}{l}\text { Positive \& } \\
\text { very weak }\end{array}$ & 0.358 & $\begin{array}{c}\text { Positive \& } \\
\text { moderate }\end{array}$ \\
\hline \multirow{2}{*}{$\begin{array}{l}\text { liquidity } \\
\text { ratio }\end{array}$} & A & 0.036 & $\begin{array}{c}\text { Positive \& very } \\
\text { weak }\end{array}$ & 0.199 & $\begin{array}{c}\text { Positive \& } \\
\text { weak }\end{array}$ & 0.199 & $\begin{array}{l}\text { Positive \& } \\
\text { weak }\end{array}$ \\
\hline & B & 0.027 & $\begin{array}{c}\text { Positive \& very } \\
\text { weak }\end{array}$ & 0.262 & $\begin{array}{c}\text { Positive \& } \\
\text { moderate }\end{array}$ & 0.149 & $\begin{array}{c}\text { Positive \& } \\
\text { weak }\end{array}$ \\
\hline \multirow{2}{*}{$\begin{array}{l}\text { operation } \\
\text { ratio }\end{array}$} & A & -0.376 & $\begin{array}{c}\text { Negative \& } \\
\text { relatively weak }\end{array}$ & -0.250 & $\begin{array}{l}\text { Negative \& } \\
\text { weak }\end{array}$ & -0.140 & $\begin{array}{c}\text { Negative \& } \\
\text { very weak }\end{array}$ \\
\hline & B & -0.256 & $\begin{array}{c}\text { Negative \& } \\
\text { weak }\end{array}$ & 0.073 & $\begin{array}{l}\text { Positive \& } \\
\text { very weak }\end{array}$ & -0.145 & $\begin{array}{l}\text { Positive \& } \\
\text { very weak }\end{array}$ \\
\hline \multirow{2}{*}{$\begin{array}{c}\text { leverage } \\
\text { ratio }\end{array}$} & A & -0.054 & $\begin{array}{c}\text { Negative \& } \\
\text { very weak }\end{array}$ & 0.018 & $\begin{array}{l}\text { Positive \& } \\
\text { very weak }\end{array}$ & 0.177 & $\begin{array}{c}\text { Positive \& } \\
\text { weak }\end{array}$ \\
\hline & B & -0.101 & $\begin{array}{c}\text { Negative \& } \\
\text { very weak }\end{array}$ & -0.010 & $\begin{array}{c}\text { Negative \& } \\
\text { very weak }\end{array}$ & 0.400 & $\begin{array}{c}\text { Positive \& } \\
\text { moderate }\end{array}$ \\
\hline \multirow{2}{*}{$\begin{array}{l}\text { profitability } \\
\text { ratio }\end{array}$} & A & -0.114 & $\begin{array}{c}\text { Negative \& } \\
\text { very weak }\end{array}$ & 0.203 & $\begin{array}{l}\text { Positive \& } \\
\text { weak }\end{array}$ & 0.255 & $\begin{array}{c}\text { Positive \& } \\
\text { moderate }\end{array}$ \\
\hline & B & -0.113 & $\begin{array}{c}\text { Negative \& } \\
\text { very weak }\end{array}$ & 0.090 & $\begin{array}{l}\text { Positive \& } \\
\text { very weak }\end{array}$ & 0.458 & $\begin{array}{l}\text { Positive } \\
\text { \&stronge }\end{array}$ \\
\hline
\end{tabular}

A: With presence of financial brokers, investment and holding.

B: Without financial brokers, investment \& holding.

\section{References}

Babic, Z., \& Plazibat, N. (1998).Ranking of enterprises based on multicriterialanalysis. International journal of production economics, 56-57, 29-35. http://dx.doi.org/10.1016/S0925-5273(97)00133-3

Conner, M. C. (1973). On the Usefulness of Financial Ratios to Investors. Journal of Accounting Review, 48(2), 551-556. http://dx.doi.org/10.1111/j.1468-5957.1987.tb00108.x

Hassanzadeh, R., Nezhadirani, F., \& Lootfelahihagi, M. (2010). The comparative investigation of financial effects on decision-Making of bank manager. Journal of Beyond Management, 3(11), 185-211.

Johnson, R., \& Soenen, L. (2003). Indicators of Successful Companies. European Management Journal, 21(3), 364-369. http://dx.doi.org/10.1016/S0263-2373(03)00050-1

Knif, J., Hogholm, K., \& Miranda, F. G. (2000). Ranked market information as a stock return indicator. The Finnish Journal of Business Economics, 2, 233-244.

Lev, B., \& Thiagrajan, S. (1993). Fundamental Information Analysis. Journal of Accounting Research, 31(2), 190-215. http://dx.doi.org/10.2307/2491270

Li, H., \& Sun, J. (2008). Ranking-order case-based reasoning for financial distress prediction. Knowledge-Based Systems, 21, 868-878. http://dx.doi.org/10.1016/j.knosys.2008.03.047

Michou, M. (2007). Investing: The Use of Financial Statements to Separate Winners from Losers. Business School of Edinburgh, University of Edinburgh, United Kingdom.

Mohanram, P. (2005). Separating Winners from Losers among Low Book-to-Market Stocks using Financial $\begin{array}{lllll}\text { Statement Analysis. Review of Accounting Studies, } 10, & 133-170 .\end{array}$ http://dx.doi.org/10.1007/s11142-005-1526-4

O'Hara, T. H., \& Vetere, J. (1993). An analysis of the Standard and Poor's Stock Appreciation Ranking System. Journal of Economics and Business, 45(2), 179-182. http://dx.doi.org/10.1016/0148-6195(93)90031-I

Omran, M., \& Ragab, A. (2004). Linear versus non-Linear Relationship between Financial Ratios and Stock 
Return: An Empirical Evidence from Egyptian Firms. Review of Accounting and finance, 3(2), 84-102. http://dx.doi.org/10.1108/eb043404

Piotroski, J. I. (2000). Value Investing: the Use of Historical Financial Statement Information to Separate Winners from Losers. Journal of Accounting Research, 38, 1-41. http://dx.doi.org/10.1080/13518470701705777

Polonchek, J., \& Krehbiel, T. (1994). Price and Volume Effects Associated with Changes in the Dow Jones Averages. The Quarterly Review of Economics and Finance, 34(4), 305-316. http://dx.doi.org/10.1016/1062-9769(94)90016-7 